\title{
Arystoteles w filozofii XX wieku - przejaw choroby czy terapii?
}

E. Berti, Arystoteles w XX wieku, tłum. A. Dudzińska-Facca, D. Facca, Warszawa 2015, ss. 270.

PAWEŁ BLEJA / Poznań /

Książka Enrico Bertiego pt. Arystoteles w XX wieku (org. włoski Aristotele nel Novecento, 1993) jest dziełem thaumastycznym (od greckiego @AYMA [THAUMA] - przedmiot godny podziwu) i nie jest bynajmniej lekturą łatwą. Jej rudymentarną cechą jest bogactwo treści i sposób argumentacji. Problematyka tej publikacji doprowadza sieci neuronalne do wysokiej aktywności, a umysł do pełni świadomości. Te efekty powstają z racji ilości i jakości omawianych przedstawicieli i kwestii. Nawiasem mówiąc Arystoteles uważał, że mózg u człowieka służy do chłodzenia organizmu (O zmystach 444a) i ta funkcja w pełni jest wykorzystywana przy lekturze niniejszej książki. Na początku przybliżmy jednak, choć prymarnie, postać autora. Notę biograficzną i charakterystykę twórczości Enrico Bertiego możemy odnaleźć w Postowiu od ttumacza (profesora Mariana Wesołego), do innej książki tego samego autora, pt. Profil Arystotelesa wydanej przez Wydawnictwo Naukowe WNS UAM w Poznaniu. (http://wns.amu.edu.pl/__data/assets/pdf_file/ooo4/ 303286/Poslowie_net.pdf). Unikając zbędnych powtórzeń zasygnalizuję jedynie najważ- 
niejsze informacje. Enrico Berti jest Włochem, urodził się 1935 roku. Studiował filozofię na Uniwersytecie w Padwie. Pełnił funkcje profesora historii filozofii na różnych uniwersytetach (Padwa, Genewa, Bruksela, Santa Fe, Lugano). Znaczące jest, że za krzewienie filozofii greckiej uzyskał doktorat honoris causa na Uniwersytecie Narodowym w Atenach. Jego formacja filozoficzna zbudowana jest wokół filozofii Arystotelesa. Jednym słowem - arystotelik. Sam Berti określa siebie samego jako „metafizyka klasycznego”. O dziwo, twierdzi nawet, że „nie jest neoarystotelikiem” (Treść niniejszej książki może ułatwić zrozumienie dlaczego nie chce tak być określany. Problematyczny, jak mniemam, nie jest termin „arystotelik”, lecz jego złożenie z przedrostkiem „neo-”). O pozycji i randze filozofa $z$ Padwy niech świadczy jego imponujący 48-stronnicowy spis publikacji. (http://fisppa.unipd.it/download/file/fid/1402)

Omawiana książka została wydana przez Wydawnictwo Instytutu Filozofii i Socjologii PAN w Warszawie w 2015 roku, a jej tłumaczami z włoskiego są Anna Dudzińska-Facca i Danilo Facca. Warto podkreślić, że jest to już druga pozycja w dorobku translatorskim Włocha, którego pierwszy „owoc” możemy kosztować zapoznając się z Wprowadzeniem do metafizyki (Warszawa 2002), również autorstwa Enrico Bertiego. W przypadku obecnie smakowanego „cytrusa z Italii” Danilo Facca jest także autorem wstępu pt. Do polskiego czytelnika. (Gwoli ścisłości pojawia się tu drobna rozbieżność, dotycząca daty ukazania się tej pozycji. Według tłumacza w 1993 roku, a wedle danych oficjalnie dostępnych w roku 1992.)

\section{Okładka może mylić}

Wstępne rozpoznanie tej pozycji wydawniczej wywołało we mnie skonfudowanie już za sprawą okładki, która może wprowadzać w błąd, gdyż przedstawia podobiznę Arystotelesa (szkoda, że pozbawiona źrenic, twarz Arystotelesa wydaje się martwa w porównaniu z Heideggerem) i zdjęcie Martina Heideggera, jedno nad drugim. Dodatkowo krótki cytat na tyle okładki odnosi się właśnie do Heideggera i wzięty jest z rozdziału Heidegger. Być może jest to celowy zabieg wydawcy służący zachęcie skierowanej do miłośników filozofii Heideggera i ukazania charakteru konfrontacyjnego wobec Stagiryty. Tymczasem pole rozważań tej książki znacznie wykracza poza myśl samego Heideggera, owszem, kluczowego przedstawiciela filozofii XX wieku. Już szybki „rzut oka” na spis treści ukazuje, że tematyka obejmuje więcej niż postać Heideggera i problematykę jego filozofii. Tytuły głównych rozdziałów to: Niemiecki neohumanizm początku XX wieku, Heidegger, Filozofia analityczna, Odrodzenie filozofii praktycznej. Książka ta, oprócz wspominanego zakłopotania, wywołała również we mnie pewnego rodzaju zażenowanie wynikające ze świadomości niewiedzy w wielu poruszanych zagadnieniach oraz z intelektualnego wyzwania, jakie stawia ta pozycja. Cóż, podjąłem wysiłek wrozumienia się w treść i oto autorska deskrypcja jej zawartości.

Cierpliwa, wymagająca skupienia lektura odkrywa moc eksplikacyjną tej książki. Nie będę ukrywał, że tekstem, który ułatwił mi przyswojenie dzieła Enrico Bertiego, był 
artykuł Danilo Facci pt. Powrót do Arystotelesa w XX wieku? Hermeneutyka, filozofia analityczna a historia filozofii. zamieszczony w pracy Antyk i wspótczesność. Recepcja filozofii starożytnej w myśli wspótczesnej (Warszawa 2015).

Jak jawi się treść książki Arystoteles $w$ XX wieku i o czym ona właściwie traktuje? Czy o wiecznotrwałej pozycji Arystotelesa? Jak filozofia XX wieku przyswajała dorobek Stagiryty? Czy myśl XX-wieczna oczyszczała twierdzenia założyciela Likejonu z naleciałości wielowiekowej tradycji? Czy może filozofowie XX-wieczni wprowadzali nowe deformacje? Na te pytania możemy znaleźć odpowiedź podczas lektury.

\section{Polscy arystotelicy w XX wieku}

Na czym polega ważność Przedmowy z roku 2008? Z perspektywy polskiego czytelnika jest ona bardzo doniosła, dostrzega bowiem polskich filozofów-logików działających w XX wieku, u których można dostrzec inspirację arystotelesowską. Autor wymienia takie nazwiska jak: Jan Łukasiewicz (1878-1956), Józef Maria Bocheński (1902-1995), Kazimierz Twardowski (1866-1938), Kazimierz Ajdukiewicza (1890-1963), Tadeusz Czeżowski (1889-1981), Tadeusz Kotarbiński (1886-1981), Stanisław Leśniewski (18861939), Alfred Tarski (1901-1983) i wciąż aktywny Jan Woleński (ur. 1940). Berti wskazuje, że z tego grona najwięcej uwagi Arystotelesowi poświęcił Łukasiewicz w książkach O zasadzie sprzeczności u Arystotelesa (Kraków 1910) oraz omówienie arystotelesowskiej sylogistyki, której oryginał uległ zniszczeniu podczas wojny, a została wydana we Włoszech pt. La sillogistica di Aristotele (Brescia 1957). Innym wspominanym polskim filozofem jest Tarski, który według Bertiego, przy tworzeniu „największego polskiego dokonania filozoficznego" inspirował się arystotelesowską koncepcją prawdy. Pisarz wymienia również dwa tytuły książek o logice Arystotelesa interpretowanej jako system formalny autorstwa Bocheńskiego Ancient Formal Logic (Amsterdam 1951) i Formale Logik (Freiburg-München 1956). To wyszczególnienie polskich filozofów, nawet jeżeli tylko we wstępie, wydaje się zjawiskiem rzadkim. Z jednej strony prowokuje do zapoznania się z polskim dorobkiem filozoficznym, z drugiej strony wskazuje na dociekliwość i otwartość autora.

\section{Dialektyczne ujęcie odpierająco-uzasadniające}

Właściwa treść książki poprzedzona jest Prologiem, krótkim zarysem recepcji Arystotelesa i dyskusji o jego filozofii od Gottfrieda W. Leibniza (1646-1716) do Eduarda Zellera (1814-19o8) i Franza Brentano (1838-1917). Ten ostatni przynależy zasadniczo do XIX wieku, lecz miał wpływ na jeden z kierunków filozofii XX wieku — fenomenologię Edmunda Husserla (1859-1938). Główną tezą przedstawioną w Prologu jest podkreślenie istnienia dwóch Arystotelesów: scholastycznego i greckiego - tego drugiego nazwałbym prymarnym. Zdaniem autora „Leibniz zainaugurował postawę, która miała przetrwać 
u wszystkich prawdziwych wielbicieli Arystotelesa w czasach nowożytnych i współczesnych" (s. 34). Berti ukazuje, że po nowożytnej rewolucji naukowej autor Fizyki wcale nie zniknął z europejskiej „sceny filozoficznej”. Wskazuje również, że nie jest prawdą, iż Stagiryta funkcjonował jedynie w zawłaszczeniu przez religię chrześcijańską (katolicką) za sprawą Tomasza z Akwinu (1225-1274), w odnowieniach w wieku XIX i XX (w 1879 roku zostaje wydana encyklika Aeterni Patris, która uznała tomizm za filozofię Kościoła katolickiego) oraz zawłaszczeniu, które pojawiło się po Soborze Watykańskim II (19621965). Berti kładzie nacisk, że w tym okresie, posługując się między innymi Heideggerem, próbowano przywłaszczyć sobie „najwybitniejszego przedstawiciela kultury «laickiej»” (s. 33), czyli Arystotelesa. Takie określenie filozofa ze Stagiry wydaje się unikatowe i wyłamujące się z tradycyjnego ujęcia.

Wbrew intencji autora zawartej w Przedmowie (s. 18) nie można tej książki traktować wyłącznie jako podręcznika historii filozofii XX wieku. Praca ta bada przecież głównie obecność filozofii Arystotelesa w myśli XX wieku. Sam autor jawi się jako rzecznik i obrońca Arystotelesa greckiego. Jego wizja filozofii XX wieku jest bardziej naświetleniem dalszych zmian dokonywanych w myśli Stagiryty, niż próbą systematycznego opisania nurtów filozoficznych w XX wieku. W tym spojrzeniu poprzez pryzmat Arystotelesa na nurty filozoficzne kryje się niezwykłość tej pracy. W książce nie znajdziemy tradycyjnego podziału filozofii XX-wiecznej na filozofię kontynentalną z jej głównymi nurtami (egzystencjalizmem, filozofią teistyczną, neomarksizmem) i filozofię analityczną reprezentowaną przez środowiska brytyjskie (Oksford i Cambridge). Następstwo rozdziałów zachowuje wprawdzie chronologię, lecz pod względem treści jest dialektyczne w rozumieniu greckim. Ta dialektyka występuje w dwóch wymiarach - w wymiarze dyskusji Bertiego z poszczególnymi reprezentantami filozofii współczesnej (szczególnie z Heideggerem) oraz w wymiarze relacji między omawianymi nurtami według schematu: nowa metafizyka Heideggera-reakcja-filozofia analityczna-reakcja-filozofia praktyczna. Zainteresowanie ze strony Bertiego Heideggerem i filozofią analityczną jest naturalne, gdyż oba nurty uwzględniały rangę filozofii Arystotelesa. Orientacją zasadniczo nieomawianą z racji proweniencji platońsko-kantowskich jest fenomenologia. Jednakże w centrum uwagi każdorazowo jest Arystoteles. Mimo takiego podejścia ujęcie Bertiego nie jest doktrynerskie - reprezentuje postawę otwartą i dyskusyjną. Berti sprawia wrażenie myśliciela, który konfrontuje rzeczywistość filozoficzną XX wieku z Arystotelesem greckim, czystym i przyjmuje postawę odpierającą, a zarazem uzasadniającą, w celu wprowadzania stabilnego punktu odniesienia.

\section{„Arystoteles Jeagera” pod wpływem neokantyzmu}

Rozdział pierwszy skierowany jest, moim zdaniem, nie tylko do Czytelników zainteresowanych niemieckimi myślicielami-humanistami takimi jak Werner Jaeger (18881961) czy Julius Stenzel (1883-1935) Przypomnijmy Jaeger to filolog klasyczny, autor prac o Arystotelesie, Platonie, wychowaniu w Grecji (Paideia), który reprezentował przeko- 
nanie, że „ukuta przez starożytnych Greków idea człowieka ma wartość klasyczną, czyli wieczną, a tym samym powinna być celem kształcenia, czyli kultury w każdej epoce” (s. 46). Julius Stenzel to również filolog klasyczny, który raczej skupiał się na Platonie. Obaj wymienieni filologowie byli właściwie rówieśnikami Heideggera. Rozdział ten ma charakter wprowadzający do omówienia poglądów Martina Heideggera i ukazuje, $\mathrm{w}$ jakim klimacie studiował i wzrastał. W tym rozdziale wyodrębnione są podrozdziały, które tworzą jedną całość (podrozdział 2, 3, 4) i charakteryzują interpretację Jaegera: Nie tylko filologia (2) ...ale odkrycie metafizyki problematycznej i krytycznej (3) ...lecz podzielonej na ontologię i teologię (4). Ten ostatni człon jest tu chyba najważniejszy i dotyczy sztucznego podziału metafizyki Arystotelesa na ontologię i teologię. (Układ dzieł jaki znamy, sięgający edycji Andronikosa z Rodos, dzieli przecież spuściznę filozoficzną na część teoretyczną: Fizykę (wraz z innymi pismami przyrodniczymi) i Metafizykę - „filozofię pierwszą", w której zagadnienia teologiczne stanowią zdecydowaną mniejszość.) $\mathrm{Na}$ tej podstawie można ukuć termin „Arystoteles Jaegera”, który ulegał z kolei interpretacji Paula Natorpa (1854-1924) - neokantysty ze szkoły marburskiej, który starał się krytykować Arystotelesa i wykazać wyższość Platona.

\section{„Przywłaszczenie” i „przemoc hermeneutyczna” Heideggera}

Osoby wybiórczo zainteresowane filozofią tzw. kontynentalną, w jej egzystencjalistycznym aspekcie, odsyłam do rozdziału 2. pt. Heidegger. Ta część osobiście przysporzyła mi najwięcej trudności, gdyż ukazuje erudycję i wprost niewiarygodną znajomość przedmiotu prezentowaną przez autora. Berti demonstruje nie tylko znajomość pism Arystotelesa, jest to raczej posiadanie dobrze uargumentowanej wizji jego filozofii, lecz również znajomość pism Heideggera wykraczającą poza kurs podstawowy. Zdaniem Bertiego Heidegger odwoływał się do Arystotelesa i dwukrotnie sformułował względem jego filozofii argumenty krytyczne. Po raz pierwszy, gdy krytykował Brentano i Arystotelesa w ujęciu scholastycznym. Po raz drugi, gdy krytykował Arystotelesa interpretowanego w duchu fenomenologii Husserla. Zdaniem Bertiego krytyka Heideggera nie stanowiła oczyszczenia z naleciałości historycznych, lecz była dodatkowym zniekształceniem. W rozdziale tym, skomplikowanym ze względu na poruszane zagadnienia, pojawia się również nowe na gruncie języka polskiego pojęcie „uniwocystyczny” (we frazie „zdradza tendencję do uniwocystycznego pojmowania bytu”). Jak rozumiem chodzi tu o pojęcie jednoznaczności od włoskiego univocità (ang. univocity)? Powróćmy jednak do Heideggera. Berti wskazuje na pewien szczegół z życia Heideggera, który miał wpływ na jego losy i rozwój myśli, a mianowicie na pobyt autora Bycia i czasu w nowicjacie Towarzystwa Jezusowego i wydalenie go ze względu na słaby stan zdrowia. Dzięki temu, na szczęście lub na nieszczęście, ostatecznie został filozofem, dla którego teologia nie była dziedziną obojętną. Warto odnotować, że istnieje pewne napięcie, które narosło poprzez wieki, polegające na rozróżnieniu na ontologię (pojęcia nieużywane przez Arystotelesa - powstało ono w XVII wieku) i teologię. W doktrynie katolickiej teologię pojmuje się 
nie jako zwieńczenie ontologii, lecz jej przeciwieństwo. (Uznaje się wyłącznie teologię opartą na objawieniu.) W doktrynie zaś protestanckiej mamy onto-teologiczną strukturę metafizyki. Teologia jawi się jako zwieńczenie ontologii i uznaje się teologię naturalną (racjonalną). Heidegger przeżył kryzys wiary katolickiej w związku z wdrażaniem się w arkana filozofii i zetknięciem z filozofią Husserla. Przeszedł od pojmowania bytu jako ousia [nie tłumaczone w tekście] do bytu jako aletheia (prawda). Według Bertiego „nowa interpretacja stanowi kolejne naciągnięcie Arystotelesa, nie mniejsze niż to, którego dokonał Brentano...” (s. 85). Heidegger wraz z odrzuceniem ontologii odrzuca również arystotelesowską „teologię”, tzn. teologię filozoficzną. Berti z całą stanowczością twierdzi: „Arystoteles jest (...) nie tyle przedmiotem «dekonstrukcji», ile przedmiotem prawdziwej «destrukcji»” (s. 92). Według Bertiego Heidegger, powołując się na Pierwszego Poruszyciela, interpretuje go w ramach idei bycia na sposób scholastyczny („bycie per essentiam”), tymczasem Pierwszy Poruszyciel u Arystotelesa to „zasadniczo myśl”. Arystoteles, znając koncepcję bytu jako ousia, której istotą jest bycie (tę koncepcję Arystoteles przypisuje Platonowi) osobiście ją odrzuca. Tekst Bertiego pełen jest wnikliwych analiz i może stanowić wzorzec krytycznego podejścia do uznanych postaci filozofii. Ogólny wniosek na tym etapie książki jest następujący: Arystoteles grecki różnił się od Arystotelesa scholastycznego, ten z kolei różni się od Arystotelesa Heideggera, co nie znaczy, że Heidegger powrócił do czystego Arystotelesa. (Notabene, nie było intencją Heideggera wskrzeszać Arystotelesa, a raczej pragnął go zastąpić. Czy można domniemywać, że Heidegger uważał Arystotelesa za geniusza, a unieważniając go, sam urastał do rangi nadgeniusza?) Heidegger dostrzegał, że w tradycji europejskiej (zachodniej) nie podchodzi się do Arystotelesa na sposób grecki. Berti uważa, że „w kwestii interpretacji metafizyki Arystotelesa [Heidegger (oraz Jaeger)] nie potrafi całkowicie wyzbyć się wpływu Kanta, który z kolei pozostawał pod wpływem interpretacji scholastyczno-nowożytnej, czyli tomistyczno-suarezjańsko-wolffiańskiej” (s. 99) Heidegger, abstrahując od motywów jego dociekań, jawi się jednak jako myśliciel, użyteczny w dochodzeniu do Arystotelesa. Krytyki Heideggera rozprawiają się z interpretacją neoplatońską, chrześcijańską i nowożytną (spinozjańską). Berti jednak, jako rzecznik Arystotelesa greckiego, dostrzega, że to, „co przedstawia [Heidegger], nie jest Arystotelesowską koncepcją bycia jako prawdy, lecz Heideggerowską, fenomenologiczną, intuicjonistyczną, czyli Husserlowską koncepcją bycia jako naoczności” (s. 109). Wnikliwość filozofa z Padwy jest oszałamiająca. Trzeba również przyznać, że prezentowane stanowisko jest efektem analiz filozofa Franco Volpiego (1952-2009), do którego odwołuje się przy tej okazji. Charakteryzując Arystotelesa heideggerowskiego, pojawiają się takie sformułowania: „przywłaszczenie”, „oddalenie się”, „inność”, „nagięcie”. Te określenia szczególnie odnoszą się do filozofii praktycznej Stagiryty. (W tym momencie wszyscy niecierpliwi mogą skorzystać z krótkiego podsumowania znajdującego się na stronie 123.)

Najciekawszy, moim zdaniem, podrozdział w rozdziale Heidegger jest zatytułowany Jedność bycia jako „dynamis” $i$ „energeia”, w którym podkreślony zostaje zwrot (tournant) do Arystotelesa greckiego. Heidegger zwraca uwagę, że należy używać greckich terminów dynamis i energeia oraz odrzucić łacińskie przekłady potentia i actus. Heidegger 
jednakże koncentruje się na tym znaczeniu owych greckich terminów, które odnosi się do ruchu, podczas gdy sam Arystoteles kładł nacisk na znaczenie filozoficzne, tzn. dotyczące bycia. Heidegger zaburza również relację między tymi pojęciami i kładzie nacisk na dynamis (s. 126). Heidegger dopuszcza się „przemocy hermeneutycznej” (sformułowanie użyte przez P. Rodrigo według przypisu), polegającej na tym, że, pragnąc przywłaszczyć sobie Arystotelesa, wkłada w jego usta przeciwieństwo tego, co mówi Arystoteles. Czy można dopuszczać do takiej przemocy? Jak często jesteśmy jej świadkami? Nawet jeśli diagnoza Bertiego nie jest słuszna, to zwrócenie uwagi na taki proceder jest niezwykle pouczające - rozwija spojrzenie wyważone, ostrożne i sceptyczne wobec tekstów uznanych, opiniotwórczych filozofów.

W konkluzji tego rozdziału znajduje się zdanie, które doskonale ukazuje różnicę między Stagirytą a Heideggerem i jednocześnie staje wyzwaniem do dalszego zastanowienia nad byciem. Fraza ta brzmi (przy czym dodatki w nawiasach kwadratowych pochodzą od piszącego te słowa, jako wyraz przyswojenia sobie podanej treści): „...wieloznaczność bycia [physis], w niezaprzeczalny sposób potwierdzona przez doświadczenie, wymaga (...) jedności, która może być ukonstytuowana jedynie przez akt [energeia], a wręcz przez taki akt, który będzie całkowicie i w pełni aktem [czynność bezruchu (energeia akinenesis)]. A jest nim właśnie akt czystej myśli. Bycie zatem jest dla Arystotelesa punktem wyjścia, a nie rezultatem dyskursu filozoficznego. Tym ostatnim jest akt [jako punkt dojścia na drodze dialektycznej], lecz nie akt pojmowany na sposób heideggerowski, czyli jako ruch, lecz pojmowany na sposób arystotelesowski: jako czynność" (s. 136). Jakie są konsekwencje takiego stwierdzenia? Odpowiedź na to pytanie pozostawiam refleksji Czytelnika.

\section{„Księstwo Arystotelesa”, które się do niego nie przyznaje}

Kolejny rozdział (3.) dotyczy filozofii analitycznej. Jeżeli rozdział o Heideggerze rozgrzewa mózg, to ten może spowodować jego przegrzanie. Ilość poruszanych wątków jest przeogromna, a ogólne ich ujęcie znajduje swe odzwierciedlenie w zdaniu: „filozofia analityczna znalazła się pod wpływem Arystotelesa i odwoływała się wprost do jego myśli” (s. 137), mając jednakże świadomość różnicy między interpretacją Arystotelesa w Oxfordzie i w Cambridge, gdzie łącznikiem między Arystotelesem a filozofią Russella i Wittgensteina był George Edward Moore (1873-1958). Moore’a, wedle Bertiego, nie można nazwać arystotelikiem, choć „zajmował się problemami omawianymi już przez Arystotelesa” i jak ukazuje Berti, to „u podstaw koncepcji filozofii jako analizy języka i poszukiwania znaczenia terminów poprzez ich oczyszczenia z wieloznaczności, wprowadzone do kultury angielskiej właśnie przez Moore’a, stoi Arystoteles” (s. 142). Klimat w Oxfordzie był znacznie bardziej proarystotelesowski. Można powiedzieć, że to właśnie tam rozwinęło się „księstwo Arystotelesa”, jego przedstawicielami stali się: John Austin (1911-1960), Gwilym E.L. Owen (1922-1982) omawiam w podrozdziale 3.2 i Gilbert Ryle (1900-1976) omówiony w podrozdziale 3.3. Według Bertiego filozofowie z Oksfordu 
przyjmują dość niespodziewaną postawę — odwołują się do Arystotelesa, jednak się do niego nie przyznają. Ryle (podobnie jak Wittgenstein) „traktują problemy filozoficzne jako chorobę, z której powinna wyleczyć terapia w postaci analizy językowej” (s. 170). Filozofowie tego nurtu przyjmują, paradoksalnie jak na filozofów, postawę zaufania do poznania naukowego (jako jedynie prawdziwego), a rezygnują z poznania filozoficznego. Dla Arystotelesa, zdaniem Bertiego, „problemy filozoficzne (aporia) są stanem godnym pozazdroszczenia, ponieważ stanowią przedsionek poznania pierwszych przyczyn, dzięki któremu człowiek staje się podobny bogu” (s. 170). Opinia zaś Bertiego o Peterze F. Strawsonie (1919-2006) - omówionym w podrozdziale 3.4 - jest następująca: „W swoim wykorzystaniu Arystotelesa ogranicza się (...) do nauki o kategoriach (...), czyli teorii wielu znaczeń bycia i prymatu substancji, ale nie wyczerpuje zadania jakie Arystoteles przypisuje «filozofii pierwszej», polegającej na szukaniu «pierwszych przyczyn» bycia jako bycia” (s. 184) Zaznacza, że filozofię analizy języka interesują zwłaszcza powiązania logiczno-językowe, bowiem powiązania typu przyczynowego nie znajdują odzwierciedlenia w strukturze języka. Te uwagi Bertiego uświadamiają, jak można zubożyć myśl Arystotelesa nawet, gdy się z niej czerpie. W podrozdziale 3.5 pojawiają się osoby związane z nurtem analitycznym i omawiani są tacy myśliciele jak Saul Kripke (ur. 1935), David Wiggins (ur. 1933), David W. Hamlyn (1924-2012) - filozofowie ci zajmują/zajmowali się problemem tożsamości. Ich stanowiska zainspirowane były Arystotelesem, szczególnie koncepcją substancji wyłożoną w księdze Z Metafizyki. Berti ukazuje wspólną cechę nie tylko filozofów analitycznych, lecz także neohumanistów niemieckich i Heideggera: nie udało im się uwolnić spod wpływu Kanta i sprowadzają metafizykę Arystotelesa do ontologii, pomijając teologię, twierdząc, że kwestie dotyczące Boga nie wchodzą w zakres metafizyki, lecz religii (s. 197). W następnym podrozdziale (3.6) omawiani są Gertrude E.M. Ascombe (1919-2001) i Georg H. Von Wright (1916-2003), uczniowie późnego Wittgensteina oraz poruszona zostaje kwestia teorii „inferencji praktycznej”, zgodnie z którą uznanie przesłanek implikuje koniecznie działanie zgodne z nimi. Von Wright uważał, że w tradycji Zachodu są dwie drogi: a) „arystotelesowska” - tendencja do wyjaśniania zjawisk poprzez finalizm, czyli przekonanie, że same zdarzenia przyrodnicze są ukierunkowane na pewien cel; b) „galileuszowa” - charakteryzuje się wykorzystaniem wyłącznie wyjaśnień typu kauzualnego, gdzie przyczyny są wyłącznie mechaniczne. Według Bertiego, powołującego się na von Wrighta, tradycja arystotelesowska utrzymała się przede wszystkim w filozofii Hegla i Marksa (sic!). Filozofia analityczna wywodząca się od późnego Wittgensteina dokonała „rewizji tradycji arystotelesowskiej” (s. 204) Schemat „inferencji praktycznej” jest analogiczny do „odwróconego” schematu wyjaśnienia teleologicznego. Wszystkie analizy i spostrzeżenia Bertiego są niebanalne i uświadamiają, jak przeszłość jest obecna we myśli współczesnej. Z racji klarowności podziału cały ten rozdział, szczególnie godny polecenia jest studentom podczas zajęć $\mathrm{z}$ historii filozofii współczesnej. 


\section{Renesans Arystotelesa w filozofii praktycznej}

Przejdźmy teraz do ostatniego rozdziału (4.) pt. Odrodzenie filozofii praktycznej. Dotyczy on zjawiska zachodzącego w filozofii kontynentalnej i w myśli amerykańskiej po II Wojnie Światowej - zwrotu ku „filozofii praktycznej”, który to termin pochodzi od Arystotelesa. Zwrot ten miał charakter polemiczny wobec poglądów Maxa Webera (1864-1920) oraz przeciw negacji ze strony analitycznej filozofii możliwości istnienia etyki opartej na poznaniu (s. 207). W nurcie antyweberowskim wymieniane są takie nazwiska jak: Leo Strauss (1899-1973), Eric Voegelin (1901-1985) i Hannah Arendt (19061975). Z kolei w nurcie antyanalitycznym wyróżnia takie osoby jak Max Horkheimer (1895-1973), Theodor W. Adorno (1903-1969) i Herbert Marcuse (1898-Z1979). Te nurty prowadziły do „rehabilitacji filozofii praktycznej” w dwóch wizjach. Pierwsza to wizja arystotelesowska - tu sytuują się tacy filozofowie jak Hans-Georg Gadamer (1900-2002), Joachim Ritter (1903-1974), Martin Buber (1878-1965) i Günter Bien (?). Druga to wizja kantowska, jej przedstawiciele to Manfred Riedel (1936-2009), Ernst Vollrath (19322003), Karl H. Ilting (1925-1984), Günther Patzig (ur. 1926). Berti koncentruje się na omówieniu nurtów o orientacji arystotelesowskiej, zaliczając do niej takich jeszcze filozofów jak Alasdair MacIntyre, Bernard Williams, Amartya Sen, Hans Jonas, Charles Perelman, Steven Toulmin, Wilhelm Hennis, Klaus Vieweg, Michael Villey, a nawet Karl-Otto Apel i Jürgen Habermas. Profesor z Padwy wskazuje, że krytyka państwa nowożytnego w nurcie proarystotelesowskim polega na „odwołaniu się do greckiego pojęcia polis i związanego z nim typu praktyki politycznej (...), i powrót do klasycznej koncepcji wiedzy praktycznej, przeciwstawionej nauce nowożytnej [o polityce]" (s. 209). Krytyka nowożytnej nauki o polityce pojawiła się również w nurcie związanym ze szkołą frankfurcką. Jaki stawiano zarzut wobec nowożytnej nauki o polityce? Mianowicie, że jest ona „niewartościująca”. Berti omawia zastrzeżenia poszczególnych filozofów w sposób jasny i przystępny, a z racji bogactwa omawianych reprezentantów trudno jest ująć jego dociekania nawet w formie streszczenia, gdyż podane przez niego informacje mają charakter skondensowany, nie będąc wiedzą encyklopedyczną. Osobny podrozdział (2.) poświęcony jest głównie Hansowi-Georgowi Gadamerowi, w którym stwierdza krytycznie wobec autora Prawdy i Metody, że „filozofia praktyczna, która u Arystotelesa była tylko częścią filozofii, w dodatku podporządkowaną filozofii teoretycznej, u Gadamera staje się całą filozofią i sprowadza się do nauczania o kluczowej roli phronesis" (s. 230). Berti, mimo że dostrzega zwrot ku Arystotelesowi, jednak widzi, że ma on charakter wybiórczy. Gadamer sprowadza filozofię Arystotelesa do filozofii praktycznej, a tę do „do określenia hermeneutycznej wartości phronesis, pod wpływem analityki egzystencjalnej lub hermeneutyki faktyczności Heideggera pojmowanej jako umiejętność zasadniczo intuicyjna" (s. 233). (Właściwie taka postawa nie może dziwić, w końcu Gadamer był uczniem Heideggera.) Ogólna charakterystyka, jaka zarysowuje się w całym tym dziale, to podział na stanowisko konserwatywne (właśnie neoarystotelesowskie), które zostaje przeciwstawione nurtowi uznawanemu za postępowy, reprezentowane np. przez Jürgena Habermasa (ur. 1923). Ta opozycja jeszcze bardziej ujawnia się w podrozdziale 3. pt. Arystotele- 
sowska filozofia praktyczna we wspótczesnej filozofii anglo-amerykańskiej. Przywołując Alasdaira MacIntyre, który w odwołaniu się do poglądu Nietzschego, że „po oświeceniu jakakolwiek etyka, zarówno typu racjonalistycznego, jak i oparta na uczuciach, nie jest możliwa” (s. 239) stwierdza, że jedyną alternatywą wobec Nietzschego jest arystotelesowska etyka cnót. Inny przywoływany filozof Bernard Williams wskazuje na „etykę arystotelesowską jako najdoskonalszy wyraz etyki starożytnej i najlepszą alternatywę zarówno wobec współczesnego utylitaryzmu, jak i wobec neokontraktualizmu” (s. 240). Poglądy takie można ująć mianem neoarystotelizmu, z którymi autor nie do końca się zgadza. Berti dostrzega, że wysunięte z kolei przez przedstawicieli etyki „dyskursywnej” (Apel, Habermas, Schnädelbach) zarzuty są słuszne wobec takiego neoarystotelizmu, który koncentruje się wyłącznie na obowiązującym zwyczaju wyrażonym w ethos oraz ogniskującym się tylko na cnocie praktycznej phronesis. Niezwykle odkrywcze jest przybliżenie takich postaci jak indyjski ekonomista Amartya Sen i niemiecki filozof Hans Jonas, którzy bezpośrednio nie odwołują się do Arystotelesa, wydobywają jednak takie pojęcia jak „dobro”, „pełen rozwój zdolności ludzkich” czy „ukierunkowanie przyrody na zachowanie życia”. Podrozdział ten jest niezwykle frapujący i inspirujący. Ostatni podrozdział (4.) w ramach oczywiście działu Odrodzenie filozofii praktycznej zatytułowany jest „Nowa retoryka” $i$ „etyka dyskursu”, a w nim znajdujemy przysłowiową wisienkę na torcie. Berti prezentuje postać głównego prekursora „nowej retoryki” - Chaima Perelmana, belgijskiego logika i filozof prawa, urodzonego w Warszawie, w rodzinie pochodzenia żydowskiego, która wyemigrowała do Antwerpii w 1925 roku. W swoich badaniach odnosił się do Topik i Retoryki Arystotelesa. „Nowa retoryka” to teoria argumentacji odwołująca się do Arystotelesa. Zdaniem Bertiego „to, co Perelman nazywa «retoryką», jest niczym innym, jak tym, co Arystoteles nazywa «dialektyką», w stosunku do której retoryka była «odbiciem» (antistrophos), w tym sensie, że podejmowała w pełni jej argumenty, uzupełniając je o rozważania na temat charakteru mówcy i uczuć słuchaczy” (s. 253). Odmienne stanowisko - „etyki dyskursu”, podzielane przez Apla i Habermasa omawiane w tym dziale z założenia nie wywodzi się od Arystotelesa. Karl-Otto Apel odwołuje się do stanowiska Kanta i Wittgensteina, Heideggera i Gadamera. Sam Apel jednak dostrzegł, że w taki wzorzec argumentacji można odnaleźć u Arystotelesa. Habermas uchodzi za najostrzejszego krytyka współczesnego neoarystotelizmu i odwołuje się do Hegla i Marksa, chociaż i w jego poglądach można dostrzec inspirację arystotelesowskie. Wszystkich zainteresowanych obecnością Arystotelesa w poglądach Habermasa odsyłam do tekstu.

\section{„Nowe przymierze” filozofii i nauki}

Książka Enrico Bertiego kończy się Posłowiem, które właściwie jest krótkim rozdziałem kolejnym (nieformalnie 5.) i dotyczy kierunków rozwoju nauk ścisłych, zasadności pytań ściśle metafizycznych, „pytania o wszystko”, „pytania o całość rzeczywistości” w kontekście myśli Marino Gentile (1906-1991), który wskazuje, że metafizyka Arystotelesa jest 
naprawdę klasyczna, jako „afirmacja problematyczności doświadczenia oraz wykazanie transcendencji zasady...” (s. 275). Warto zwrócić uwagę na podrozdział 1. Posłowia pt. Nowa epistemologia. Znajdują się w nim stwierdzenia, można powiedzieć, rewolucyjne np. „Konieczne staje się (...) nowe przymierze filozofii i nauki, zainspirowane nie galileuszowsko-newtonowską tendencją do stosowania do zjawisk ziemskich modelu zjawisk niebieskich, lecz tendencją przeciwną, polegającą na stosowaniu modeli ziemskich do zjawisk niebieskich, to znaczy tendencja właściwa filozofii arystotelesowskiej” (s. 267). Berti odwołuje się do poglądów głoszonych przez laureata nagrody Nobla w dziedzinie chemii, pochodzenia rosyjskiego Ilyi Prigogine’a (1917-2003). Poglądy rehabilitujące Arystotelesa głosi również Rene Thom (1923-2002) francuski matematyk, twórca tzw. „teorii katastrof”, który odnajdywał teorię ciągłości w Fizyce Arystotelesa, jako własne wyzwanie badawcze zrealizowane w swojej teorii. (Paradoksalnie w naszej świadomości ciągle pokutuje mit o nieaktualności fizyki Arystotelesa, że powinni zajmować się nią jedynie historycy nauki.) W dziedzinie nauk biologicznych można też inspirować się ciągle Arystotelesem, o czym świadczą amerykańscy biolodzy Max Dellbrück (19061981) i Ernst Mayer (1904-2005) wskazujący na wartość finalizmu arystotelesowskiego.

Ostatnim podrozdziałem Posłowia jest akapit zatytułowany Dlaczego Arystoteles? Warto do niego zajrzeć i zadać sobie pytanie o aktualność Arystotelesa. Sama książka dotyczy przecież wieku, który już przeminął i można powiedzieć, że wymagane są dalsze studia nad wiekiem następnym - XXI. W tym sensie można powiedzieć, że książka ta jest anachroniczna. (Zwłaszcza, że niestety dopiero w roku 2016 mamy możliwość jej przeczytania w języku polskim.). Mówiąc jednak o anachroniczności można też nadać temu pojęciu odmienne niż słownikowe znaczenie. Należy myśleć o tej wybitnej książce raczej w wymiarze ponad- i pozaczasowości. Mówiąc lakonicznie, w kategoriach filozofii i kultury greckiej, trzeba docenić jej arete - doskonałość.

\section{Dobrze filozofować (sumphilosophein) z Enrico Bertim}

Czy obecność filozofii Arystotelesa w myśli XX-wiecznej należy traktować jako przejaw choroby czy też terapii? Przywołując medyczne porównanie, w którym chorobę traktujemy jako stan odchodzenia od zdrowia, a terapię jako proces dochodzenia do niego, spróbujmy odpowiedzieć na to pytanie. Chciałbym wyrazić przekonanie, że interpretowanie filozofii XX-wiecznej wraz z heroldem arystotelizmu - Enrico Bertim ma cechy rozumoterapii. Jasność wyrażania myśli, sprecyzowany własny punkt widzenia okazuje się niezwykle instruktywny. Gdyby jednak uznać, że partycypacja Arystotelesa w XX wieku jest ostatecznie „chorobą” to książka ta, mam nadzieję, przyczyni się do jej rozprzestrzenienia. 